\title{
Q.H. Vuong's Book at YUL
}

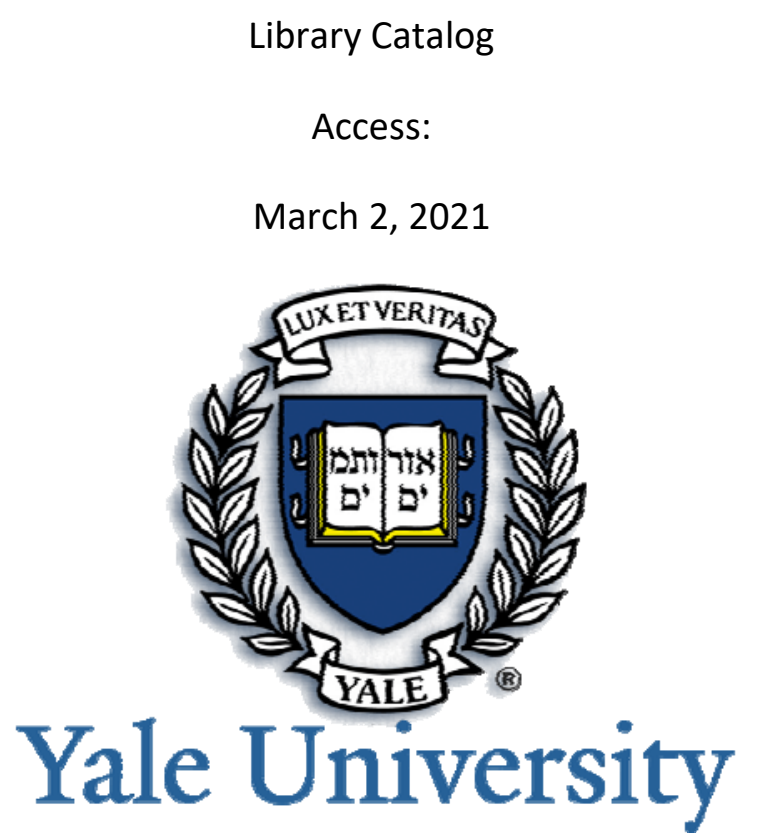

Yale University

Querying URL:

https://search.library.yale.edu/catalog?q=Quan+Hoang+Vuong

The search results in one book by Q.H. Vuong, which follows.

1. Kinh tế Việt Nam: thăng trầm và đột phá

SML, Stacks, LC Classification

HC444 .P446X 2009 (LC)

Available at YUL from: June 28, 2011

https://search.library.yale.edu/catalog/9320447 
March 1: Bass Library reopened; Sterling and Bass resume evening and weekend hours. Yale Library COVID-19 updates

\section{Quicksearch}

\section{Kinh tê Việt Nam : thăng trầm và đột phá}

Author

Phạm, Minh Chính.

Title

Kinh tê Việt Nam : thăng trâm và đột phá / Phạm Minh Chính, Vương Quân Hoàng.

Published

Hà Nội : Nhà xuât bản Chính trị quỏc gia, 2009.

Physical

Description

xxx, 554 p. : ill. ; $23 \mathrm{~cm}$.

Summary

Portraits of strategy and development of economic in Vietnam.

Format

E Books

Language

Vietnamese

Added to

Catalog
June 28, 2011

Bibliography

Includes bibliographical references (p. 539-549) and index.

Subjects

Economic development $>$ Vietnam $>$ History.

Structural adjustment (Economic policy) $>$ Vietnam $>$ History.

Vietnam > Economic conditions > 1975-

Also listed

under

Vương, Quân Hoàng

Bookmark As

https://search.library.yale.edu/catalog/9320447

\section{Available from:}

SML, Stacks, LC Classification

HC444 .P446X 2009 (LC)

Request for pickup $\rightarrow$

Request scan of article / chapter $\rightarrow$

Send to home address or campus residence $\rightarrow$

$\checkmark$ Available

More info at Google books 


\section{Bibliography}

Phạm Minh Chính, Vương Quân Hoàng. (2009). Kinh tế Việt Nam: Thăng trầm và Đột phá. Nxb Chính trị Quốc gia, Hà Nội. 